\title{
Status of Gastrochilus minimus (Orchidaceae) - a recently described species from China
}

\author{
Bhattacharjee A. ${ }^{1 *}$, Agrawala D.K. ${ }^{2}$, Jalal J.S. ${ }^{2} \&$ C. Deori ${ }^{3}$ \\ ${ }^{1}$ Central National Herbarium, Botanical Survey of India, P.O. Botanic Garden, Howrah, West Bengal - 711 103, India \\ ${ }^{2}$ Botanical Survey of India Headquarters, CGO Complex, 3rd MSO Building, Block F, Sector I, \\ Salt Lake City, Kolkata - West Bengal, 700 064, India \\ ${ }^{3}$ Botanical Survey of India, Eastern Regional Centre, Lower New Colony, Laitumkhrah, Shillong, Meghalaya - 793 003, India \\ ^E-mail: avibsi@rediffmail.com
}

\begin{abstract}
Gastrochilus minimus J.W.Li, D.P.Ye \& X.H.Jin, a recently described orchid from China, is taxonomically merged with Gastrochilus sessanicus A.N.Rao. The former name is not effectively published as of September 2021, even after online availability of the 'In Press, Corrected Proof' version since February 2021 on the journal's website. We intend to address this issue at the forthcoming International Botanical Congress as the situation regarding the backdating of the publication date for unchanged versions (i.e. with unchanged content) of an electronic publication is not explicitly mentioned in the Code. This sinking of $G$. minimus extends the distribution of G. sessanicus which has been considered as endemic to India for the last 25 years. A detailed description of the species and photographs of the holotype of G. sessanicus and that of the specimen cited as 'holotype' of G. minimus are provided. A global Red List assessment of G. sessanicus is presented as per IUCN guidelines.
\end{abstract}

Keywords: Aeridinae, Epidendroideae, Gastrochilus sessanicus, Heterotypic, Vandeae.

\section{Introduction}

The genus Gastrochilus D.Don (EpidendroideaeVandeae-Aeridinae) is represented by $c .63$ species and one natural hybrid, with a distribution from Sri Lanka and India to Indonesia and the Philippines (Ormerod \& Kumar, 2020). Singh et al. (2019) reported 20 taxa under this genus from India, of which six are endemic. Gastrochilus sessanicus

Received: 05.08.2021; Revised \& Accepted: 29.09.2021

Published Online: 16.10 .2021
A.N.Rao was described in 1997 based on a specimen (A.N. Rao 29273) collected from Sessa, West Kameng district of Arunachal Pradesh, India, in 1996, which is preserved at the Orchid Herbarium Tipi, Arunachal Pradesh (not in 'Index Herbariorum'; here abbreviated as OHT). However, there is another specimen (A.N. Rao 29420) of this species at OHT, which was collected by Rao. This specimen was collected before the collection of the holotype, but was not cited in the protologue due to the lack of flowers or fruits (pers. comm. with A.N. Rao on 12.9.2021). As it is evident from the label-data of the specimen that Rao studied the specimen before publishing G. sessanicus, it is part of the original material of the name vide Art. 9.4 of the ICN (Turland et al., 2018), but not a type or paratype. Gastrochilus sessanicus is the only representative from India for the section Caespitosi Z.H.Tsi of Gastrochilus. The species is diagnosed by its very small habit with short or obscure, erect stem erect with a few leaves, more or less flabellate arrangement of sepals and petals, subconical hypochile with a keel on abaxial surface, obtuse and entire apex of hypochile, and triangular to flabellate epichile, which is densely pubescent/hirsute adaxially with an elliptic central cushion, abaxially with a keel or broad conical swelling subterminally, and an epichile with slightly reflexed apex.

Li et al. (2021, final version in press) described Gastrochilus minimus J.W.Li, D.P.Ye \& X.H.Jin (not effectively published by 26.9.2021) based on 
specimens collected from the Yixiang township, Simao district, Yunnan province, China. While describing G. minimus, the authors compared their species with $G$. acinacifolius Z.H.Tsi, but they overlooked G. sessanicus. After studying the image of the holotype of G. sessanicus and that of the specimen cited as holotype in the prospective protologue of $G$. minimus, we are of the opinion that all the characters of G. minimus fall within the range of variation of $G$. sessanicus. Though Rao (1997) described the leaf-apex as acuminate with three setae, it actually ranges from shortly acuminate to acute as evident from the holotype (A.N. Rao 29273, OHT!) and original material (A.N. Rao 29420, OHT!) of G. sessanicus. The presence of setae at the leaf-apex is not a stable character in Gastrochilus. It is caducous at different stages of maturity (Agrawala et al., 2021). Therefore, G. minimus is treated here under G. sessanicus as there is no distinct and stable character that can morphologically differentiate these two species. A detailed description of G. sessanicus and the photograph of the holotype of G. sessanicus and that of the specimen cited as 'holotype' in the prospective protologue of G. minimus are provided here. An illustration of $G$. sessanicus can be found in Rao (1997) and photographs of G. minimus and dissected floral parts are provided by Li et al. (2021, final version in press).

The paper on G. minimus by Li et al. (2021, final version in press) was published online on February 3, 2021 and marked as 'In Press, Corrected Proof' and as of September 2021 the volume, issue and page numbers are not assigned to it. The journal's web page notes: "Corrected proofs are Articles in Press that contain the author's corrections. Final citation details (e.g., volume and/or issue number, publication year, and page numbers) still need to be added and the text might change before final publication. Although corrected proofs do not have all bibliographic details available yet, they can be cited using the year of online publication and the DOI as follows: author(s), article title, publication (year), DOI..... When the final article is assigned to a volume/issue of the publication, the Article in
Press version will be removed and the final version will appear in the associated published volumes/ issues of the publication. The date the article was first made available online will be carried over". An electronic publication may be a final version even if details, e.g. volume, issue, article, or page numbers, are to be added or changed, provided that those details are not part of the content" (see Art. 30.2, Note. 1; 30.3: Turland et al., 2018).

Therefore, according to ICN Art. 30.2 the name G. minimus is not validly published because the publisher has not considered the corrected proof as final version (see Art. 30.2, Ex. 4: Turland et al., 2018) evidenced by the publisher's statement '...the text might change before final publication' (see above). Unfortunately, even if there would be changes in the content for the final version, the publication will still carry the same date (February 3,2021 ) as per the journal's policy on which the 'In Press, Corrected Proof' version was available online. Such publications, carrying much earlier dates of 'In Press, Corrected Proof' versions, may affect the priority of other validly published names which are actually published earlier and satisfying the necessary rules of the Code. We intend to address this issue at the forthcoming International Botanical Congress as the situation regarding the backdating of the publication date for unchanged versions (i.e. with unchanged content) of an electronic publication is not explicitly mentioned in the Code.

In the present case, we are treating G. minimus under G. sessanicus even though it had not been effectively published by September 2021. When the name will be effectively published in future (perhaps backdated to February 3, 2021), it should be treated as a 'synonym' of G. sessanicus by validly publishing the same in any printed/electronic material based on the taxonomic decision presented here. In any case, even if the name $G$. minimus is not effectively published in the future, the present communication will still serve to establish the extended distribution range of $G$. sessanicus which has so far been considered as endemic to India for the last 25 years. 


\section{Taxonomic Treatment}

Gastrochilus sessanicus A.N.Rao, J. Orchid Soc. India 11: 1. 1997. Type: INDIA, Arunachal Pradesh, West Kameng district, Sessa, 1100 m, 20.11.1996, A.N. Rao 29273 (holo. OHT!). Gastrochilus pumilus D.P.Ye \& H.Jiang, Wild Orchid Yunnan 476. 2010, nom. inval. Gastrochilus minimus J.W.Li, D.P.Ye \& X.H.Jin, Plant Diversity, https://doi.org/10.1016/j.pld.2021.01.009 (2021, published online: corrected proof version; final version in press), nom. inval. (as of 26.9.2021).

Epiphytic herbs; up to $4 \mathrm{~cm}$ high. Stems $1-3 \mathrm{~cm}$ long. Leaves 3-6, elliptic-lanceolate to ovatelanceolate, $1.5-4 \times 0.4-0.8 \mathrm{~cm}$, closely arranged on short stem, acute to acuminate, sometimes with three setae at apex, sessile, green, sometimes tinted purple adaxially. Inflorescences sub-umbellate, 1 or 2, extra-axillary, $0.5-1.8 \mathrm{~cm}$ long, 2-8-flowered.
Floral bracts ovate-lanceolate to triangular, 0.09$0.3 \times 0.09-0.2 \mathrm{~cm}$, acute, slightly incurved, beaked at apex. Flowers small, $0.7-1.0 \mathrm{~cm}$ across, with green to yellowish-green sepals; petals dotted with purple-red or with reddish stripes; labellum yellowish-green to pale whitish-yellow with purple-red central cushion adaxially, dotted with purple-red mostly near rim of the sac. Pedicelled ovary $0.3-0.5 \mathrm{~cm}$ long. Sepals subsimilar, ellipticoblong or spatulate, $0.32-0.35 \times 0.12-0.17 \mathrm{~cm}$, concave, often keeled externally along mid-vein, rounded to obtuse-acute at apex. Petals ellipticoblong to oblanceolate, $0.25-0.28 \times 0.14-0.15 \mathrm{~cm}$, keeled externally along mid-vein, sometimes slightly erose at upper margins, subacute to rounded at apex. Labellum attached with base of column; hypochile saccate, subconical, $0.2-0.3 \mathrm{~cm}$ long, abaxially with keel, obtuse, entire at apex; epichile triangular to flabellate, $0.2-0.25 \times 0.4-0.5 \mathrm{~cm}$,
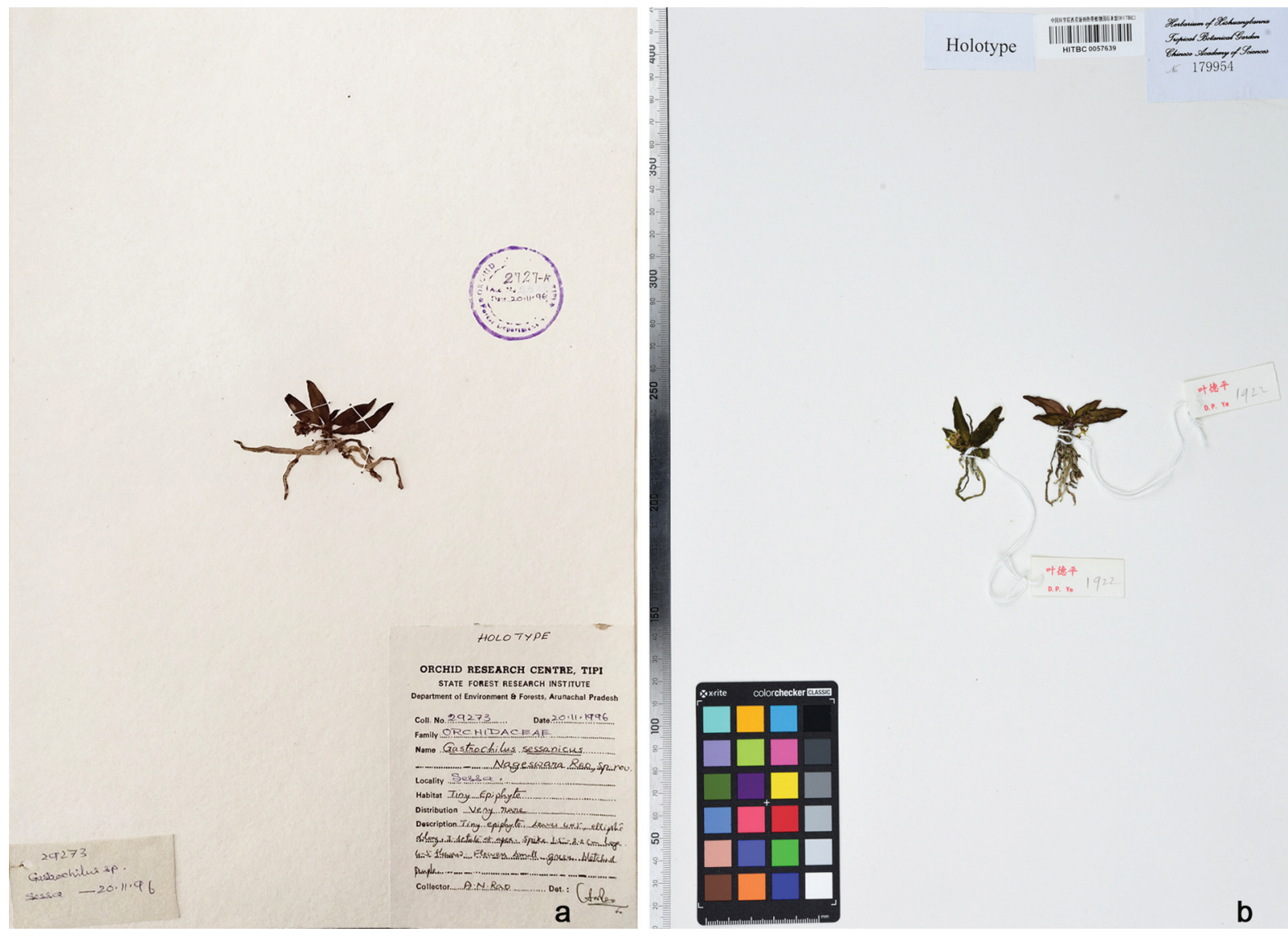

Fig.1. a. Holotype of Gastrochilus sessanicus A.N.Rao preserved at OHT (@ Orchid Herbarium Tipi, Arunachal Pradesh, India); b. Specimen cited as 'holotype' of G. minimus J.W.Li, D.P.Ye \& X.H.Jin at HITBC (@ HITBC). 
densely hairy to hirsute on upper surface, along margins, with elliptic cushion on upper surface, keel or broad conical swelling sub-terminally on lower surface, slightly reflexed at apex. Column 0.12-0.15 $\mathrm{cm}$ long, broader at base; rostellum bilobed. Anther $0.1-0.15 \mathrm{~cm}$ long; pollinia 2, globular, porate; stipe filiform, 0.06-0.1 cm long; viscidium oblong, $0.03-$ $0.06 \mathrm{~cm}$ long; fruits not observed.

Flowering \& fruiting: Flowering from JulySeptember in China; October-November in India; fruiting not observed.

Habitat: Growing on moss covered slender branches of small trees in wet evergreen subtropical mixed, coniferous broad-leaved forests at 1100 m elevation.

\section{Distribution: China and India.}

Etymology: The specific epithet was coined after the type locality (Sessa) of the species.

Specimens examined: CHINA: Yunnan province, Simao district, Yixiang township, N $22.79^{\circ}$, E $100.97^{\circ}, 1287 \mathrm{~m}, 13.09 .2020$, D.P. Ye 1922 (HITBC, photo; specimen cited as holotype of G. minimus). INDIA: Arunachal Pradesh, West Kameng district, Sessa, 16.09.1996 (not in fl.), A.N. Rao 29420 (OHT).

Conservation status: Gastrochilus sessanicus was until now considered endemic to India. However, it was found to be present in China under different names (G. pumilus, nom. inval. and G. minimus, nom. inval.), which have now been treated under G. sessanicus.
Li et al. (2021, final version in press) have estimated the suitable habitat of this species in China to be less than 500 ha. $\left(=5 \mathrm{~km}^{2}\right)$, harbouring around 200 mature individuals and considered its threat status as 'Critically Endangered' [CR B1ab(iii) $+2 \mathrm{ab}(\mathrm{iii})]$ based on single location and decline in quality of habitat. Globally, the species is known to exist at only two distinct sites, in China and India, constituting an Area of Occupancy (AOO) of 8 sq. $\mathrm{km}^{2}$ (Fig. 2). According to A.N. Rao (pers. comm., 12.9.2021) the type locality (Sessa, India) had less than half a dozen mature individuals only in 1996 and after that, he could not observe any individual. The two localities in India and China are separated by a distance of nearly $900 \mathrm{~km}$ and hence, the possibility of gene flow between them is highly unlikely. This implies that the species can be considered 'Severely Fragmented' at present. However, it is a fact that not much area in between the two localities is properly explored, particularly in Myanmar, and it is possible that the species can be found in more localities in future. The extent and quality of habitat are on the decline due to developmental work, broadening of roads, tourism and other anthropogenic activities even at Sessa in India and its surrounding area. Hence, the species can be assessed as 'Critically Endangered' [CR B2ab(iii)] at present following IUCN guidelines (IUCN 2019).

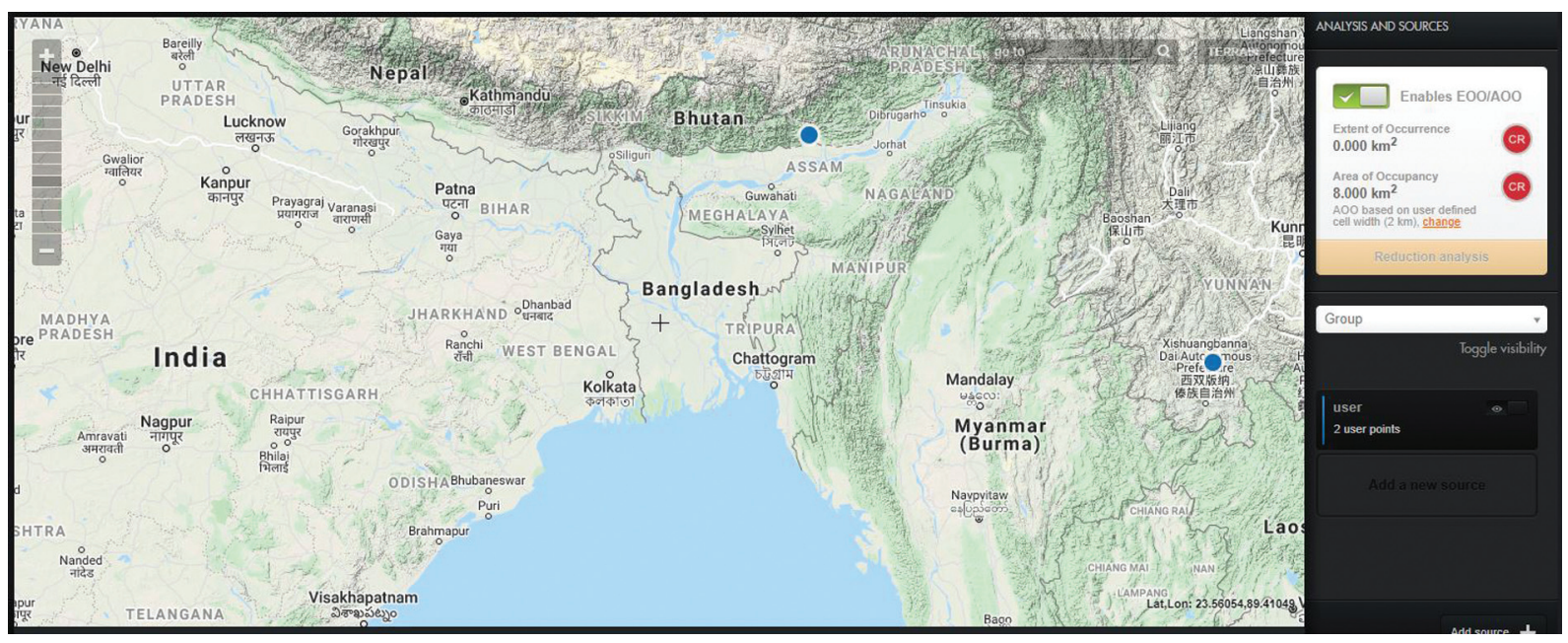

Fig. 2. Global distribution map of Gastrochilus sessanicus A.N.Rao [Map created in GeoCAT platform http://geocat. kew.org.]. 
Note: The colour, size, density and intensity of blotches on perianth and colour of the perianth as a whole are variable (Seidenfaden, 1988) in several species of Gastrochilus. The minute differences in size of some floral parts between plants/ subpopulations fall under range of variation only due to climatic/altitudinal factors.

\section{Acknowledgements}

The Director, Botanical Survey of India (BSI), Kolkata, and Head of Offices of our respective Units/Regional Centers provided research facilities and encouragements. Dr. A.N. Rao, Orchidologist and the author of $G$. sessanicus offered his valuable opinion on the identity of G. minimus and supported our observations on these two species. Dr. Kothareddy Prasad, former Post-Doctoral Fellow of BSI, provided good-quality photograph of the holotype of G. sessanicus. The Scientist-in-charge of OHT provided permission to study the specimens during our visits and Dr. Jian-Wu Li (the first author of G. minimus) of HITBC for sending us photograph of the specimen cited as 'holotype' of G. minimus with permission to publish the same. Dr. Subir Bandyopadhyay, retired Scientist of BSI helped with his valuable suggestions. The reviewers are thankfully acknowledged for their useful comments.

\section{Literature Cited}

AGRAWALA, D.K., BHATTACHARJEE A., JALAL J.S. \& C. DEORI 2021. Gastrochilus yei (Orchidaceae) - a new addition to the orchid flora of India. Nelumbo 63:
29-32. https://doi.org/10.20324/nelumbo/v63/2021/ 165148

IUCN 2019. Guidelines for using the IUCN Red List Categories and Criteria. Version 14. Prepared by the Standards and Petitions Committee. Available at: http:/ /www.iucnredlist.org/documents/RedListGuidelines. pdf.

LI J.-W., YA J.-D., YEE D.-P., LIU C., LIU Q., PAN R., HE Z.-X., PAN B., CAI J., LIN D.-L. \& X.-H. JIN 2021 (published online: corrected proof version; final version in press). Taxonomy notes on Vandeae (Orchidaceae) from China: five new species and two new records. Plant Diversity, https://doi.org/10.1016/ j.pld.2021.01.009 (Available online on 3 February, 2021).

ORMEROD P. \& C.S. KUMAR 2020. A new Bhutanese Gastrochilus (Orchidaceae), and another transfer in Indian Cylindrolobus. Harvard Papers in Botany 25: 125127. https://doi.org/10.3100/hpib.v25iss1.2020.n16

RAO A.N. 1997. A new species of Gastrochilus from Arunachal Pradesh (India). The Journal of the Orchid Society of India 11: 1-3.

SEIDENFADEN, G. 1988. Orchid genera in Thailand XIV: fifty-nine vandoid genera. Opera Botanica 95: 1-398.

SINGH S.K., AGRAWALA D.K., JALAL J.S., DASH S.S., MAO A.A. \& P. SINGH 2019. Orchids of India: a pictorial guide. Botanical Survey of India, Kolkata.

TURLAND N.J., WIERSEMA J.H., BARRIE F.R., GREUTER W., HAWKSWORTH D.L., HERENDEEN P.S., KNAPP S., KUSBER W.H., LI D.-Z., MARHOLD K., MAY T.W., MCNEILL J., MONRO A.M., PRADO J., PRICE M.J. \& G.F. SMITH (eds.) 2018. International Code of Nomenclature for algae, fungi and plants (Shenzhen Code) adopted by the Nineteenth International Botanical Congress Shenzhen, China, July 2017. Regnum Vegetabile 159, Volume 38. Koeltz Botanical Books, Glashütten. https:/doi.org/ 10.12705/Code. 2018 